\title{
THE NEW FEDERAL RULES OF CRIMINAL PROCEDURE: I
}

\author{
GEORGE H. DESSION $\dagger$
}

ON March 21, 1946, a new set of rules of criminal procedure for the federal courts went into effect. Hailed by former Attorney General Homer Cummings as "a triumph of the democratic process," 1 this body of rules is the non-legislative product of a laborious, eight-year enterprise which required the participation of a great many individuals and groups throughout the United States, including judges, lawyers, government officers, legal scholars, and committees of bench and bar. In contrast with the unwieldy legislative codes of criminal procedure of many of the states, these rules occupy but sixty small pages of large print. ${ }^{2}$ In a pocket edition, as the late Judge George Z. Medalie once remarked, they would take up no more space than a box of matches.

\section{History}

The movement to extend this type of rule-making to federal criminal procedure generally dates back to 1938 , originating "as an integral part of a broad program for simplicity and efficiency in all branches of judicial administration." 3 The Criminal Appeals Rules had been promulgated by the Court in $1934,{ }^{4}$ to be followed in 1941 by the Petty Offense Rules. ${ }^{5}$ In 1938 the Attorney General initiated the present

† Lines Professor of Law, Yale University; Member of the United States Supreme Court Advisory Committee on Rules of Criminal Procedure.

1. Cummings, The New Criminal Rules-Another Triumph of the Democratic Process (1945) 31 A. B. A. J. 236.

2. Rules of Criminal Procedure For the District Courts of the United Statrs (1946) U. S. Gov. Printing Office.

3. Vanderbilt, Foreword, The New Federal Criminal Rules (1942) 51 YALE L. J. 719-20: "The federal system of courts did not attain its present symmetry of district courts, circuit courts of appeals, and a Supreme Court without considerable experimentation. The Administrative Office of the United States Courts was born of turmoil. [See (1927) 23 A. B. A. J. 385,387 . The proposal for a "Proctor" was favored by 39,990 lawyers, opposed by 23,841 , whereas the proposal to enlarge the Supreme Court was favored by 18,533, opposed by $51,156$.$] The act granting the rule-making power in civil cases to the Supreme Court was$ passed only after a crusade by the bar lasting thirty years. [See Supreme Court Adopls Rules for Civil Procedure in Federal District Courts (1938) 24 A. B. A. J. 97.] In contrast, the act conferring on the Court the rule-making power in criminal cases up to verdict [54 STAT 688,18 U. S. C. 687 (1940)] was passed without opposition, largely as a result of the example of the Civil Rules and of the Act of 1934 conferring on the Court rule-making power in criminal cases after verdict. [47 STAT. 904 (1933), as amended 48 Star. 399 (1934), 18 U. S. C. $\S 688$ (1940)]. The Supreme Court's broad rule-making powers now cover not only traditional civil and criminal proceedings but also such fields as bankruptcy and copyright cases."

4. Order of May 7, 1934, 292 U. S. 661. The enabling legislation under which these rules were promulgated does not require submission to Congress.

5. Order of January 6, 1941, 311 U. S. 733, pursuant to the Act of Oct. 9, 1940, 54 SraT. 1058, 18 U. S. C. $\$ \S 576-576 \mathrm{~d}(1940)$. This enabling legislation does not require submission to Congress. 
movement, ${ }^{6}$ and the House of Delegates of the American Bar Association promptly adopted a resolution urging adoption of the necessary enabling legislation. Arthur T. Vanderbilt was appointed chairman of a special committee of the Association to prepare such legislation, and shortly thereafter Senate 1283 and House of Representatives 4587 were introduced. Hearings were held before a sub-committee of the House Judiciary Committee in May, 1939. Enactment of the necessary legislation was in turn urged by Justices Murphy and Jackson during their terms as Attorney General, and endorsed by the late President Franklin D. Roosevelt in a letter to the American Law Institute on May 9, 1940.7 The measure became law on June 29, 1940. ${ }^{8}$

Early in 1941 the Court appointed an Advisory Committee to assist in the preparation of the contemplated "rules of pleading, practice, and procedure with respect to proceedings prior to and including verdict, or finding of guilty or not guilty, in criminal cases in district courts of the United States," 9 and the Committee held its first meeting at Washington on February 21, 1941 for preliminary discussion. The procedure then agreed upon was essentially that which had been so successfully employed by the earlier Advisory Committee on Rules of Civil Procedure. Successive drafts would be prepared by the Reporter and his staff, assisted by members of the Committee. Each draft would then be reviewed and revised, section by section, at a meeting of the full Committee. (Typically, such a meeting consumed four days). Preliminary drafts so prepared would be published and dis-

6. Cummings, $A$ Rounded System of Judicial Ralk-Afaking (1938) 24 A. B. A. J. 513; Selected Papers of Honer Cunnmas (Swisher's ed., 1939), 181 et sei.; Cummings, Extending the Rule-Ifaking Power to Federal Criminal Procedure (1938) 22 J. Ads. Jub. Soc. 151; REP. AtT'Y GEN. (1938), Item No. IV, at 4.

7. Cummings, The Newo Criminal Rules-Another Triusmpls of the Deriocratic Process (1915) 31 A. B. A. J. 236, 237-S.

8. 54 STAT. 688 (1940), 18 U. S. C. $§ 687$ (Supp. 1945). This act provides that "Such rules shall not take effect until they shall have been reported to Congress by the Attorney General at the beginning of a regular session thereof and until after the close of such resion, and thereafter all laws in conflict therewith shall be of no further force and effect."

9. Order of February 3,1911, 312 U. S. 717. The original members of the Committee were Arthur T. Vanderbilt, Newark, New Jersey, Chairman; James J. Robincon, Profescor of Law at the Indiana University Law School, Reporter; Judge Alevander Holtzoff, Washington, D. C., Secretary; the late Newman F. Baker, Professor of Law at the Northwestern University Law School; Judge George James Burke, Ann Arbor, Michigan; John J. Burns, Boston, Mass.; Judge Frederick E. Crane, New Yorls City; Gordon Dean, Washington, D. C.; Sheldon Glueck, Professor of Law at the Harvard Law School; the late Judge George Z. Medalie, New York City; Lester B. Orfield, Professor of Law at the University of Nebraska Law School; Murray Seasongood, Cincinnati, Ohio; J. O. Seth, Santa Fe, New Mexico; John B. Waite, Professor of Law at the University of Michigan Law School; Herbert Wechsler, Professor of Law at the Columbia Law School; G. Aaron, Youngquist, Minnea polis, Minnesota; and the writer. George F. Langsdorf, of Oaliland, California, mes added by Order of May 26, 1941, 313 U.S. 602; and Judge Hugh D. MicLellan, of Boston, Macsachusetts, by Order of October 27, 1911,314 U. S. 719. 
tributed (by permission, but without the sanction of the Court) to all interested persons and groups, and in particular to local, state and federal committees of the bench and bar organized for the purpose, to invite criticism and suggestions.

In May, 1943 the Committee published a Preliminary Draft, with notes and forms, this being a revision of six successive confidential drafts prepared in the Committee. ${ }^{10}$ Rules to govern appeals, as well as proceedings up to and including verdict, were included, pursuant to two orders so extending the Committee's assignment. ${ }^{11}$ After further revision a Second Preliminary Draft, of similar scope, was printed and circulated in February, 1944. In June, 1944 the Committee met to consider further suggestions and to revise the Second Preliminary draft, and transmitted its final report to the Court in July, 1944. ${ }^{12}$ With certain revisions, the rules governing proceedings up to and including verdict were adopted by the Court and transmitted to the Attorney General on December 26, 1944 to be reported to the Congress at the beginning of the regular session on January 3, 1945. ${ }^{13} \mathrm{~A}$ rule regulating criminal appeals by the United States under the Act of May 9, 1942 was likewise reported to the Congress on the same date, having been transmitted by the Court to the Attorney General on December 30, 1944. ${ }^{14} \mathrm{~A}$ volume of notes to the rules governing proceedings up to and including verdict, prepared under the direction of the Advisory Committee, was published in March, $1945 .{ }^{15}$ In addition

10. The first was dated September 8, 1941; the second, January 12, 1942; the third, March 4, 1942; the fourth and fifth, May, 1942; and the sixth, fall of 1942.

11. By Order of November 17, 1941, 314 U. S. 719, the Committee was authorized and directed "to make such recommendations as may be deemed advisable respecting anendments to the rules promulgated by this Court pursuant to the provisions of the Act of Congress, approved March 8, 1934, amending an Act entitled 'An Act to give the Supreme Court of the United States authority to prescribe Rules of Practice and Procedure with respect to proceedings in criminal cases after verdict' (Act of February 24, 1933, c. 119, 28 U. S. C., $\$ 723$ (a) )."

By Order of October 26, 1942, 317 U. S. 715, the Committee was authorized and directed "to make such recommendations as may be deemed advisable respecting promulgation of rules of practice and procedure," pursuant to the Act of May 9, 1942 (Public Law 543, 77th Congress), authorizing the Court to promulgate rules governing appeals by the United States in certain cases.

12. Federal Rules of Criminal Procedure, Report of tae Advisory Committee (1944).

13. Rules of Criminal Procedure for the District Courts of tue United States (1944). See letter from The Attorney General transmitting Rules of CRiminal Procedure For the District Courts of the United States, H. R. Doc. No. 12, 79th Cong., 1st Sess. (1945).

14. Letrer from The Attorney General transmitting a Rule Regulating Criminal Apreals By The United States, H. R. Doc. No. 3, 79th Cong., 1st Sess. (1945). The enabling act is 56 STAT. 271 (1942), 18 U. S. C. A. $\S 682$ (Supp. 1945).

15. Notes to the Rules of Criminal Procedure for tie District Courts of tue UNITEd States (1945). 
to the rules thus reported to Congress, the Court adopted, with certain modifications, the rules prepared by the Advisory Committee to govern proceedings after verdict. The complete set of rules and recommended forms, including the latter rules, as promulgated by the Court, was published in 1946.16 This last together with the volume of notes mentioned above constitute the end product.

In addition to the above legislative, committee and judicial history of the rules, there is already a considerable literature. ${ }^{17}$ Most of the articles by Committee members were written while the enterprise was still in progress, and reflect the policy considerations which moved the Committee. Those by others constitute but a small fraction of the response to the Committee's invitation of suggestions and criticism of the preliminary drafts.

The value of this latter phase of the rule-making procedure as a means of perfecting the product, and of winning its acceptance, can hardly be over-stressed in the light of the Advisory Committee's experience. The procedure depends upon the Advisory Committee taking the initiative and bearing the brunt of the research, the initial policy decisions and policy formulation. But the Committee also served, as former Attorney General Homer Cummings has expressed it, as "a conduit through which judges, prosecutors, attorneys, government officials and others interested in the functioning of criminal justice, throughout the length and breadth of the land, could present their problems and make known their needs." Through the ramifying

16. Rules of Crnimal. Procedure For The Distruct Cougts of tale Uzited STATES (1946). The rules governing proceedings after verdict, which were not required to be reported to Congress, are numbered 32-39.

17. Federal Rules of Crimitula Procedure mitr Notes and Isstitute ProcecoINgs (1946); Barron, Proposed Rules of Proced are int Criminal Cases, 2 F. R. D. 211; Berge, The Proposed Federal Rules of Criminal Procedure (1943) 42 MIrcr. L. REv. 353; Berge, Some Comments on the Proposed Federal Rales of Criminal Procedure (1943) 34 J. Crus. L. 222; Cummings, The New Crimizual Rales-Another Tritumpli of the Denceralic Process (1945) 31 A. B. A. J. 236; Cummings, A Rounded System of Judicial Rule-mahing (1938) 24 A. B. A. J. 513; Cummings, The Third Great Adcenture (1943) 29 A. B. A. J. 654; Dean, Rule-11aking for Crimizal Procedure (1940) 24 J. Asr. Jub. Soc. S1; Dession, The Propased Federal Rules of Criminal Procedure (1941) 18 Cons. B. J. 58; Hall, Objectices of Federal Criminal Procedural Resision (1942) 51 Y.aLe L. J. 723; Harno, Proposed Rules of Federal Criminal Procedure: Final Draft (1944) 42 MIICE. L. Rev. 623; Holtzoff, Codificalion of Federal Criminal Procedure FED. BaR. J., Oct. 1944, 1S-37; Holtzoff, Rcform of Frderal Critminal Procedure (1944) 12 Geo. Wash. L. Rev. 119, 3 F. R. D. 445; Holtzoff, Ths Kight of Counsel Under the Sistli Amendment (1944) 20 N. Y. U. L. Q. KEv. 1; Holtzoff, Some Problems of Federal Criminal Procedure (1912) 9 J. B. A. D. C. 554; 10 Id. 69, 2 F. R. D. 431; Howard, Evidence in Federal Criminal Trials (1942) 51 YALE L. J. 763; Longedorf, New Federal Rules of Criminal Procedare (1913) 18 Calif. STate B. J. 263; Mlaguire, Progosed Nico Federal Rules of Criminal Procedure (1913) 23 ORE. L. Rev. 56; Miedalie, Fcderal Rules of Crimiral Procedure (1911) 4 Lawyers Gumd Rev. (3) 1; Orfield, Improsing Procediste on Judgmmb and Appeal in Federal Criminal Cases (1943) 27 Mrsw. L. Rev. 169, 2 F. R. D. 573; Orfield, Preliminary Draft of the Federal Rules of Criminal Procedare (1943) 22 TEx. L. REv. 191, 
network of circuit, state, district and local committees, the grass roots were tapped. The result was "a code of criminal procedure imposed neither by legislature nor by court-but originating from every informed source." Only through some such procedure could so comprehensive and integrated a reformulation of principles be translated in so short a time into law in a society such as ours. The validity of the procedure is demonstrated by the practical experience of the legal profession with the earlier Federal Rules of Civil Procedure. ${ }^{18}$

\section{Policy}

The importance attributed by all involved to fair and effective federal administration of criminal justice is evident from the fact that the rule-making project was not suspended during the war. Indeed, it was felt that the war heightened that importance. War creates new strains on most institutions, including those concerned with the fair

221; Phillips, Suggestions and Comments on Proposed Federal Rules of Criminal Procedure (1943) 17 Fla. L. J. 230; Robinson, Proposed Federal Rules of Criminal Procedure (1943) 27 J. AM. JuD. Soc. 38; Rossman, $A$ Study of Rules 10,11,12,13,14, 15, 16 and 17 of the Federal Rules of Criminal Procedure with Particular Respect to their Suitability for Adoption into State Criminal Procedure (1945) 25 ORE. L. Rev. 21; Seasongood, Proposed Federat Rules for Criminal Procedure (1942) 13 Mo. B. J. 163; Stewart, Comments on Federal Rules of Criminal Procedure (1943) 8 JonN Marshall L. Q. 296; Tibbs, Criminal Procedure Under Proposed Federal Rules Compared with Wisconsin Statutes (1944) 28 MARQ. L. REv. 75; Vanderbilt, Foreword, The New Federal Criminal Rules (1942) 51 YALE L. J. 719; Vanderbilt, New Rules of Federal Criminal Procedure (1943) 29 A. B. A. J. 376; Waite, The Proposed Federal Rules of Criminal Procedure (1943) 27 J. Asr. Jud. Soc. 101, 103; Winters, A Study 'of Rules 6, 7, 8, and 9 of the Federal Rules of Criminal Procedure with Particular Respect to Their Suitability for Adoption into State Criminal Procedure (1945) 25 ORE. L. REv. 10.

18. The New Criminal Rules-Another Triumplt of the Democratic Process (1945) 31 A. B. A. J. 236, 237. In this connection it may be noted that the rules were not unanimously adopted. Mr. Justice Black stated that he did not approve, and Mr. Justice Frankfurter filed a dissenting memorandum. 323 U. S. 821 (1944). Cf. Mr. Cummings' response (id., 238) to the considerations advanced by Mr. Justice Frankfurter:

"There is occasionally heard some dissent on the ground that the justices of the Supreme Court, removed from direct day-by-day contact with trials in the district courts, are without opportunity to observe what rules of procedure are best calculated to promote the largest measure of justice. But plainly the Supreme Court's role in these rule-making projects has been largely that of moderator or arbitrator rather than arbitrary lawgiver-a function which, in a large sense, it exercises daily in its regular work. Moreover, appellate judges gain a great deal of objective knowledge concerning procedural needs from their examination of appellate records in cases actually tried in the lower courts.

"The question has also been raised whether an appellate court should be charged with the duty of promulgating a procedural code, since such a code can hardly escape provisions in which serious questions may lurk for future adjudication. This consideration, however, could in no event be more serious than the problem of stare decisis which the Supreme Court faces so frequently. As a matter of fact, the Supreme Court has not been embarrassed in the least degree in passing on questions arising under the Federal Rules of Civil Procedure which it had previously approved. Moreover, the continuing power to amend rules once adopted en- 
and just preservation of order. ${ }^{19}$ There had, moreover, been a significant expansion in federal criminal law well antedating the war. The vast development of federal regulation, particularly since 1933, had brought more and more classes of the population, and more and more business operations, within the direct orbit of federal criminal sanctions. It appeared probable that the war, with its inevitable after-complications, could not but accelerate this trend. .9

The rules work no revolutionary reforms. Some restate existing law. Others involve substantial changes. By and large those changes consist in adoption of modern practices developed in the more progressive states and in England. A few are new. The prime values sought to be served throughout were, as declared in Rule 2, "simplicity in procedure, fairness in administration and the elimination of unjustifiable expense and delay." 21

To bring together in one comprehensive code all of the rules governing a federal criminal proceeding was considered advantageous to

ables the Court to make such timely modifications as actual esperience may suggest."

19. See Vanderbilt, Foreward, The New Federal Criminal Rules (1942) 51 YaLE L. J. 719, 722:

"In a world torn by international conflict, with national defence our primary responsibility at the moment, there may be lawyers as well as laymen who wonder why time and thought should now be devoted to the formulation of federal rules of criminal procedure. They should be reminded that these rules will expedite the prompt and efficient trial not only of ordinary criminals but of the many pereons suspected of being saboteurs or enemy agents. But, even more important, they should be reminded that the international conflict is essentially a struggle between law and order on the one side and brute force on the other. Our type of civilization depends on 'equal justice under law:' The present international struggle is not merely political; on the contrary, our primary goal is the preservation of freedom in our own country and its restoration elsewhere. One has but to lools bacls to the many criminal prosecutions arising in World War I to realize that in times of crisis there is always a tendency to disregard the individual's civil rights and liberties. In our zeal to achieve ultimate victory, we must not cast aside the very thing we are fighting for."

20. Robert F. Maguire has expressed the practitioner's reaction in Proposed Nero Federal Rules of Criminal Procedure (1943) 23 ORE. L. Rev. 56:

"I may say . . . in view of the vastly enlarged powers of the Federal Government, which seem to have no termini as far as those powers concern the adoption of new rules and regulations, as well as statutes which have criminal aspacts, it is not at all unlikely that we are going to have to overcome our reluctance to practice criminal law, as it will be absolutely necessary for anyone who expects to lool: after the business of his clients to accept criminal cases, because every individual and business is now directly affected by rules and regulations having criminal aspects."

21. Some of the sources from which the rules spring are discussed in Orfield, The Preliminary Draft of the Federal Rules of Criminal Procedure (19:3) 22 TEx. L. REv. 37, 41-2. The present writer would be inclined to place less emphasis on the Aurericny LAT Itisniute CODE of Crnnnal Procedure, and more on the high degree of consensus which emerged from the wide range of personal background experience in criminal law administration represented by the committee as an aggregate, and from collaborating groups as rell. 
courts, prosecutors, defendants and defense counsel alike. Prior to March 21, 1946 federal criminal procedure could fairly be described as chaotic. Some matters were governed by piecemeal legislation, enacted at different times, and without apparent effort to achieve an integrated, cohesive system. As to other matters, common law prevailed; in the areas subject to the conformity principle, federal procedure looked to the common law as modified by the constitutions, statutes, and decisions of the courts of the states. To the occasional practitioner in the federal courts this was naturally confusing, and even experienced federal judges and practitioners were recurrently subjected to what would otherwise have been unnecessary technical research.

Uniformity in practice on a nation-wide basis was also desired. Lawyers practicing in more than one federal district, like judges assigned from one district to another, were obliged to adjust to the varying procedures in criminal cases in the several districts. The methods of examining prospective petit jurors and of exercising peremptory challenges were far from uniform. In most districts the Government was entitled to open and close in argument to the jury, while in others the government opened and the defense was entitled to close. The practice governing the examination of the jury for cause varied in respect of whether the voir dire should be conducted entirely by the court, entirely by counsel, or by both court and counsel. Some of the courts, following the lead of the new civil rules, were dispensing with the necessity for the constant taking of exceptions, while others continued to require it. Varying practices obtained as to the content and grounds for demurrers, motions to quash and pleas in abatement, and there was disagreement as to whether such pleas and motions might be joined in one document. With respect to jury instructions, most courts required that separate requests be submitted prior to argument and instructed the jury at the conclusion of argument; but even here there was variation. ${ }^{22}$

This is not to say, however, that different local conditions do not dictate different arrangements and details of practice in a variety of respects. In a metropolitan district a large number of judges sit the year round. Commissioners and counsel are readily available. Distances are short. In a sparsely settled rural district-as in the Southwest, for example-opposite conditions obtain. In any given division there may be a criminal term for but a week or two, once or twice a year. Distances create problems with respect to speedy arraignment, the assignment of counsel, time provisions and so on. Since a uniform set of federal rules had to prescribe a practice suitable for all districts, it was necessary that the rules be general and flexible, prescribing only basic essentials, rather than rigid and detailed.

22. Dean, Rule-Making for Criminal Procedure (1940) 24 J. Asr. Jud. Soc. 81, 82-3. 
Another characteristic more or less peculiar to federal criminal law and administration also favored general rules. In contrast to the relatively simple character of the vast majority of criminal cases prosecuted in the state courts, many federal cases-anti-trust, war fraud, mail fraud, sedition, conspiracy, and the like-are extremely complex, requiring months and even years to try. Obviously, unique problems of procedural adjustment must be resolved in such cases if the judicial machinery is to fulfill its function. But even in federal practice, a system of procedure geared primarily to the requirements of these complex cases would be unsatisfactory for the ordinary run. The complex cases bulk larger in the work of the appellate courts than in the day to day flow of business in the district courts. The average case is not appealed, and does not find its way into the law reports. Indeed, the great majority of criminal cases are disposed of on plea of guilty. It follows, as Judge Holtzoff has remarked, that a "distorted view of criminal procedure in actual operation would be obtained by concentrating attention on the decisions of the appellate courts in these few criminal cases that reach the appellate stage, or even by confining one's study to the procedure followed in the more important cases or occasional cause celebre." 23

The rule-making process in the field of procedure is, of course, no newcomer to Anglo-American legal tradition, ${ }^{24}$ and its advantages of

23. Holtzoff, Some Problems of Federal Criminal Procedure (1912) 9 J. B. A. D. C. 554, 557.

24. See Medalie, Federal Rules of Crimiszal Procedure (1944) 4 Lawyens Gumb Rev. (3) $1:$

"When, in 1940, Congress conferred upon the Supreme Court the power to make rules of criminal procedure (18 U. S. C. A. $\$ 687$ [Supp. 1945] ), theretofore exercised solely by Congress, it restored a practice which had been a tradition of the English and Roman Law.

"Throughout the development of the English law, Parliament at no time undertook to chain the Courts to a legislative code of procedure. Even where statutes were enacted for the regulation of civil procedure, as in the Civil Proccdure Act of 1833 and the Procedure Act of 1852, the judges were authorized to malse such alterations in the rules of pleadings and practice as they might deem expedient. Thus, English practice achieved the same result accomplished by the Romans, whereby each praetor upon coming into office announced the rules which would govern litigation. In this flexible way, successive praetors built up the procedure which has become an integral part of the Anglo-American jurisprudence.

"It was not until the middle of the 19th century that there was a change in this concept of granting to the judiciary the authority to malse rules governing judicial procedure. The Field Code, enacted in New York in 1848, established a precedent which, widely followed, had an indelible effect on the procedure of the various states. In the 1920 s and $1930 \mathrm{~s}$, this legislative freezing of rules of Court breame the subject of vigorous criticism. The New Yorl Code was called a 'political and economic blunder of the first magnitude' and it was observed that it 'set a precedent which changed the American judicial establishment from a living stream into 3 -stagnant pool.' This view met with vigorous assent by Profs. Wigmore and Pound. 
flexibility are obvious. Legislative bodies have neither the time nor the facilities to inquire into detailed problems of judicial procedure or to formulate complete codes, and typically have failed to do so. The alternative of leaving the formulation of rules of procedure to ordinary judicial process presents the disadvantage that that process is necessarily limited to dealing with specific questions in particular cases as they happen to arise. Hence the numerous conflicts between the various circuits, and the number of important questions which have sometimes gone unresolved for years. Quite recently, for example, the Supreme Court has had before it such unresolved basic questions as that of the limits on the detention and interrogation of arrested persons prior to arraignment, ${ }^{25}$ of the meaning and scope of the right to counsel, ${ }^{26}$ and of the power of courts to correct various types of errors after the time within which a motion for new trial may be made has elapsed. ${ }^{27}$

\section{SCOPE AND Application}

The rules went into effect on March 21, 1946, in the sense that they are applicable to proceedings commenced thereafter, and likewise, "so far as just and. practicable," to proceedings then pending. ${ }^{28}$ They govern all types of criminal proceedings in the federal courts, including the Circuit Courts of Appeals and the Supreme Court of the United States, and proceedings before United States commissioners, with a few minor exceptions. ${ }^{29}$ In addition to federal courts in the continental United States, they include the District Courts in Alaska, Hawaii,

Prof. Wigmore made the somewhat startling observation that legislative rule making was unconstitutional as violative of the separation of powers doctrine of the Federal and State Constitutions."

25. McNabb v. U. S., 318 U. S. 332 (1943).

26. Adams v. U. S. ex. rel. McCann, 317 U. S. 269 (1943).

27. Wells v. U. S., 318 U. S. 257 (1943).

28. Rule 59.

29. Rule 54(a). The exceptions are found in Rule 54(a) and (b), and include preliminary proceedings before state magistrates empowered to commit persons charged with offenses against the United States; removal proceedings from state courts; trials before United States commissioners and in the district courts under the Act of October 9, 1940, c. 785, 54 STAT. 1058-1059, 18 U. S. C. $\$ 576-576 \mathrm{~d}$ (1940) relating to petty offenses on federal reservations, those being governed by the existing rules promulgated by the Supreme Court on January 6 , 1941, 311 U. S. 733 (1941); extradition and rendition of fugitives; forfeitures; the collection of fines and penalties; summary trials for offenses against the navigation laws under REv. STAr. $\$ \S 4300-4305$ (1875), 33 U. S. C. $\$ \S 391-396$ (1940); proceedings involving disputes between seamen under REv. STAT. $\$ \$ 4079-4081$, as amended, 22 U. S. C. $\$ \$ 256-258$ (1940); proceedings for fishery offenses under the Act of June 28, 1937, c. 392, 50 STAT. 325-327 (1937) 16 U. S. C. $\$ \S 772-7721$ (1940); and proceedings against a witness in a foreign country under the Act of July 3, 1926, c. 762, 44 STAT. 835 (1926), 26 U. S. C. $\$ \S 711-718$ (1940).

The rules are likewise not applicable to proceedings under the Federal Juvenile Delin. quency Act "so far as they are inconsistent with that Act." [Rule 54(b)(5)]. They do not alter the power of judges of the United States or of United States commissioners to hold to security of the peace and for good behavior under the Act of March 3, 1911, c. 231, 8270 , 
Puerto Rico and the Virgin Islands; and the rules governing proceedings after verdict include the District Court of the Canal Zone as well.:3

There was no effort to formulate and include in the rules a complete code of evidence, not because this would not have been within the Court's rule-making power, but because it was felt by the Committee that the rules of evidence should in most respects be the same for criminal as for civil proceedings. As in the Civil Rules, however, the subject was not left untouched. Rule 26 provides:

"In all trials the testimony of witnesses shall be taken orally in open court, unless otherwise provided by an act of Congress or by these rules. The admissibility of evidence and the competency and privileges of witnesses shall be governed, except when an act of Congress or these rules otherwise provide, by the principles of the common law as they may be interpreted by the courts of the United States in the light of reason and experience." 31

The rule thus codifies the principle declared in Funk v. United Slates ${ }^{32}$ and Wolfe $v$. United States, ${ }^{33}$ to the effect that in criminal trials in federal courts both the competency of witnesses and the admissibility of testimony will be governed, in the absence of Congressional enactment, - not by local law but by common law principles as interpreted by the federal courts "in the light of reason and experience." The reference

36 STAT. 1163 (1911), 28 U. S. C. $\$ 392$ (1940), and under REv. STaT. $\$ 4069$ (1875), 50 U.S. C. $\$ 23(1910)$. Such proceedings, however, shall conform to these rules "so far as they" are applicable."

30. Rule 54(a)(1). The rules do not apply to proceedings before the Supreme Courts of Hawaii or Puerto Rico, these being purely local appellate courts having no jurisdiction over the district courts of the United States in those territories. See Notes to IRE RULES OF Crnitral Procedure for the District Courts of the Utited States (1945) 4t-5.

31. Compare the phrasing of the last clause of this rule in Federal Rules of Crusmal Procedure, Prelnimary Draft (1943): ". . . by the principles of the common law as interpreted by the courts of the United States." The above language was criticized in Additional Statenent by Messrs. Dession, Gluece, Orfield, asid Wecksler, id. at 255-6, as follows:

"The purpose of the rule is to codify the existing law, as developed by the Supreme Court in Funk v. U. S., 290 U. S. 370 and Wolfe v. U. S., 291 U. S. 7. We believe that its purpose is sound. We fear, however, that the rule as drafted may be taken to refer to the 'principles of the common law' in some narrower sense than the decisions upon which it is based. To avoid this danger we think it safer to adhere more closely to the language of the opinions and to adopt as the guiding criterionwhen no act of Congress or rule othervise provides-'the principles of the common law as they may be interpreted by the courts of the United States in the light of reason and experience.' This fuller statement will indicate that in parsing upon evidence questions the courts may look not only to the older decisions but also to enlightened statutory developments in the states. It will make plain that what is contemplated is a judicial function which is continuously creative to an exceptionally high degree."

32. 290 U.S. 371 (1933).

33. 291 U. S. 7 (1934). 
is not to the common law as of 1789 , as of the date of admission of any given state into the Union, or of any given state at the present time. The federal courts are free to take cognizance of altered conditions, of the course of legislative change, and of the weight of current judicial authority. This approach contemplates the development of a uniform body of rules of evidence for federal criminal trials, unlike Civil Rule 43(a) which provides for partial conformity in civil proceedings. Existing federal statutes dealing with the admissibility of evidence and the competency and privileges of witnesses-collected in the Committee Note to this rule - are expressly continued. Rules 27 and 28 deal with more particular evidential problems-"Proof of Official Record," 34 and "Expert Witnesses." 35

The qualifications of jurors are not prescribed by the rules. Here again, it was felt that the problem was common to civil and criminal proceedings. The Committee did, however, approve the report and legislation to prescribe uniform qualifications for jurors recommended by the Knox Committee of the Conference of Senior Circuit Judges, ${ }^{30}$. and suggested that the proposals of the Knox Committee be embodied in a rule applicable to both types of proceedings. ${ }^{37}$

34. Rule 44 of the Federal Rules of Civil Procedure is here incorporated by reference, providing a simple and uniform method of proving public records and entry or lack of entry therein. The numerous federal statutes providing modes of proof in respect of specific official records are not superseded. For an enumeration of these, see Notes to TUE RULES of Criminal Procedure for the District Courts of the United States (1945) 25-28. The effect of Rule 44 is to give an option to proceed according to the rule or to the pertinent statute.

35. Rule 28 provides as follows:

"EXPERT WITNESSES. The court may order the defendant or the government or both to show cause why expert witnesses should not be appointed, and may rcquest the parties to submit nominations. The court may appoint any expert witnesses agreed upon by the parties, and may appoint witnesses of its own selection. An expert witness shall not be appointed by the court unless he consents to act. $A$ witness so appointed shall be informed of his duties by the court at a conference in which the parties shall have opportunity to participate. A witness so appointed shall advise the parties of his findings, if any, and may thereafter be called to testify by the court or by any party. He shall be subject to cross-examination by each party. The court may determine the reasonable compensation of such a witness and direct its payment out of such funds as may be provided by law. The particy also may call expert witnesses of their own selection."

A court, of course, has the power to call witnesses of its own motion. See Notes To tuic Rules of Criminal Procedure for the District Courts of the United States (1945) 28. The purpose of the rule is to provide a procedure whereby the court may, if it chooses, exercise this power in respect of expert witnesses. Cf. THE UNIFORM EXPERT TestimonY Act, Handbook of the National Conference of Commissioners on Uniform State Laws (1937) 337; Wigarore, Evidence (3rd ed. 1942) §563; A. L. I. Code of Criminal Procedure (1931) §§ 307-309.

36. Report to the Judicial Conference of The Comaittee on Selection of JURoRs (September, 1942).

37. See Letter of The Chairman, Federal Rules of Criminal Procedure, PreliarNARY DRAFT (1943) xvi. 


\section{Prelmitarary Proceedings}

The Complaint. Rule 3 provides that the complaint shall be "a written statement of the essential facts constituting the offense charged" and "made upon oath before a commissioner or other officer empowered to commit persons charged with offenses against the United States." This involves no major departure from the previous practice, ${ }^{33}$ but the former requirement of conformity to state law is eliminated." The rule does not specify whether the complaint may be based on information and belief rather than personal knowledge, leaving this question to be determined by each district court." Nor does the rule expressly provide that federal complaints may not still be filed with various state and local magistrates-a practice not very frequently involed, but authorized by Section 591 of Title 18, U.S.C. These local magistrates are thus still "empowered" to receive complaints within the meaning of the rule, and proceedings had before them would presumably continue to be governed by local practice, the new federal rules being inapplicable to those tribunals.

Warrant or Summons upon Complaint. One new feature of Rule 4 is the provision that "Upon the request of the attorney for the government a summons instead of a warrant shall issue." The summons has been the established method for bringing a defendant corporation before the court, ${ }^{41}$ and the rule now sanctions the same procedure for natural defendants, when appropriate. Employment of this method, familiar in many of the states, and in England, ${ }^{42}$ will often save time and expense, and avoid unnecessary humiliation of defendants. Use of a letter or telephone call in lieu of a warrant to bring in responsible defendants has, of course, always been possible. The rule simply regularizes and encourages such exercise of discretion by prosecuting

38. See United States v. Simon, 248 Fed. 980 (E. D. Pa. 1916); United States v. Maresca, 266 Fed. 713, 719-21 (S. D. N. Y. 1920).

39. The Act of May 2S, 1896, c. 252, $\S 19$, as amended, 29 Stat. 184, 31 Star. 956 (1901), 18 U. S. C. $\$ 591$ (1940), provided that persons might be arrested and imprisoned "agreeably to the usual mode of process" of the state in which proceedings were held. Some states require that the complaint be in writing, while others do not. Some require perconal knowledge, while others accept a complaint on information and belief.

40. Rule 57 (b) provides: "If no procedure is specifically preseribed by rule, the court may proceed in any lawful manner not inconsistent with these rules or with any applicable statute." See Notes to the Rules of Criminal Procedure for the District Courts OF THE UNTTED STATES (1945) 55: "One of the purposes of this rule is to abrogate any existing requirement of conformity to State procedure on any point whatsoaver. The Federal Rules of Civil Procedure have been held to repeal the Conformity Act. Sibbach v. Wilson, 312 U. S. 1, 10."

41. 36 STAT. 1162 (1911), 28 U. S. C. $\$ 377$ (1940) (Power to issue writs); United States v. John Kelso Co., 86 Fed. 304 (N. D. Cal. 1S98); see also Albrecht v. United States, 273 U. S. $1, S$ (1927).

42. See Notes to the Rules of Cruminal Procedure for the District Counts of THE UNTED StATES (1945). 
attorneys. The mode of service prescribed is substantially the same as in civil actions under Civil Rule 4(d)(1). No contempt procedure for the enforcement of a summons is prescribed, since failure to respond can be met by the issuance of a warrant.

With regard to warrants of arrest, there are several new features. Rule 4(a) provides, inter alia, that "More than one warrant or summons may issue on the same complaint." This has been the practice in some districts, but in others the practice has been to issue but one warrant even for defendants jointly indicted. ${ }^{43}$ The present provision, together with that in subdivision (e)(3) that "The officer need not have the warrant in his possession at the time of the arrest, but upon request he shall show the warrant to the defendant as soon as possible," will facilitate execution and return in such cases, especially when the defendants must be arrested at different times and places.

Another innovation is the provision in subdivision (c)(2) of the rule that "The warrant may be executed or the summons may be served at any place within the jurisdiction of the United States." This is designed to eliminate certain steps which formerly were necessary when a defendant was arrested in a district other than that in which the prosecution was instituted: (1) return of the original warrant non est inventus, and (2) obtaining a new warrant in the district in which the defendant is found. ${ }^{44}$ Now the original warrant constitutes sufficient authority to arrest the defendant in any district, but does not affect his rights as to removal. 45

The rule also contains a convenient new provision concerning the return of a warrant or summons. Subdivision (c)(4) provides:

". . . At the request of the attorney for the government any unexecuted warrant shall be returned to the commissioner by whom it was issued and shall be cancelled by him. . . . At the request of the attorney for the government made at any time while the complaint is pending, a warrant returned unexecuted and not cancelled or a summons returned unserved or a duplicate thereof may be delivered by the commissioner to the marshall or other authorized person for execution or service."

The purpose is to obviate the former necessity of issuing new warrants in cases where the defendant could not be apprehended for some time. ${ }^{40}$ Proceedings before the Commissioner. The controversial problem as

43. Notes to the Rules of Cruminal Procedure for the District Courts of tue UNITED STATES (1945) 2.

44. Mitchell v. Dexter, 244 Fed. 926 (C. C. A. 1st, 1917); Palmer v. Thompson, 20 App. D. C. 273 (1902).

45. See Rule 40.

46. Cf. Rev. Stat. $\S 1028$ (1875), 18 U. S. C. $\S 603$ (1940) (Writs; copy as jailer's authority), and REv. STAT. $\S 1014$ (1875), 18 U. S. C. $\$ 591$ (1940), dealing with the return of "copies of process." 
to how long an arrested person may be detained prior to arraignment for questioning and investigation is left about where it was by the provision in Rule 5(a) that the arresting officer "shall take the arrested person without unnecessary delay before the nearest available commissioner or before any other nearby officer empowered to commit persons charged with offenses against the laws of the United States." Previously the time standard was embodied in the several statutes governing the various categories of federal officers authorized to make arrests. Variously phrased-one governing arrests by the F.B.I. required arraignment "immediately," and one governing the alcohol tax unit read "forthwith"-all were construed to impose similar duties of prompt arraignment. ${ }^{47}$ The rule restates that duty without substantial change and, like the statutes, does not specify the consequences of non-compliance. ${ }^{48}$ The history-maling policy laid down by the Supreme Court in $M I c N a b b$ v. United States ${ }^{49}$ and subsequent cases, to the effect that admissions or confessions obtained from a suspect while he is being held prior to and without prompt arraignment shall not be admissible in evidence, therefore remains in full force.

This new policy is reasonably clear. The idea that arrest should be permitted only on "probable cause," and the corollary that one arrested should promptly be arraigned before a judicial officer to assure an objective determination of that issue, developed out of the experience of the English common law. The idea is incorporated in the Bill of Rights, and in the several federal statutes prescribing the duties of arresting officers.

The difficulty, in the view of many enforcement officials, is that there are serious crimes, especially when committed by organized groups,

47. The most important statutes are 28 STAT. 416 (1894), as amended, 18 U. S. C. $\S 595$ (1940); 20 Stat. 341 (1879), 18 U. S. C. $\$ 593$ (1940); 4 S Sr $A$ r. 1008 (1934), as amended, 5 U. S. C. $\$ 300$ (a) (1940). Others are collected in Notes to tre Rules of Crusmial PEOCeduRe for the Distruct Courts of tae United States (1945) 4. For diseucsions of the meaning of prompt arraignment under these and similar statutes see Carroll v. Parry, 48 App. D. C. 453 (1919); Janus v. United States, 38 F. (2d) 431 (C. C. A. 9th, 1930); and Warner, The Uniform Arrest Act (1912) 28 VA. L. Rev. 315, 339-341. Cf. A. L. I. CODE OF Cenminal Procedure (1931), Commentaries to $\$ \$ 35,36$.

48. The first Preliminary Draft contained a provision [5 (b)] that no statement made by a defendant in response to interrogation by an officer or agent of the government should be admissible in evidence against him if the interrogation occurred while the defendant ras held in custody in violation of subdivision (a). Interestingly enough, though evolved prior to the decision of the Supreme Court in MicNabb v. United States, 318 U. S. 332, (1943) this provision stated much the same principle. Nevertheless, it evolied a storm of protest in prosecution, bar association, and even judicial circles, and was eliminated in the subsequent drafts. Representative samples of these protests are quoted in Waite, Eridence-Pobice Regulation by Rules of Evidence (1941) 42 Mirca. L. REv. 679.

49. 318 U. S. 332 (1943); Anderson v. United States, 318 U. S. 350 (1943); United States v. Mitchell, 322 U.S. 65 (1941); Ashcraft v. Tennessee, 322 U. S. 143 (1944). 
which cannot be solved unless suspects may be held incommunicado and questioned until they disclose what they know. Public opinion wants the spectacular cases solved, and apart from those there are, of course, many cases in which the same procedure will yield results more readily than legally sanctioned but more laborious techniques of investigation. Bruce Smith expressed the police point of view in 1929:
". . . it must be remembered that police are creatures of legisla- tive enactments, and that their control has sometimes been dictated by some of the wildest vagaries of the legislative imagination. This definition and restriction of powers has at times been carried so far, and the police have found themselves confined within such narrow limits in both administration and criminal investigation, that they have made furtive, and occasionally open efforts to circumvent the laws under which they operate." 50

Faced with these considerations the state courts-and, prior to the $M c N a b b$ decision, the federal courts as well-have been accustomed to compromise. They have not said that arrest on suspicion or incommunicado detention can be lawful, and a person so held is entitled to release on habeas corpus-assuming that he has someone to procure the writ for him in time. Police indulging in these practices are subject to discipline and even criminal penalties, and in exceptional cases of public scandal these sanctions have sometimes been applied. Offending police officers may also be sued, and in cases where a person mistreated has turned out to be entirely innocent or possessed of unanticipated influence, substantial damage verdicts have sometimes resulted. But the courts have consistently sanctioned the admission in evidence of confessions obtained from suspects who were being unlawfully held so long as the confessions were not shown to be otherwise "involuntary" or suspect. ${ }^{51}$

The compromise has not been limited to cases of exceptional gravity and time urgency. The police understandably prefer the leeway which it affords. The difficulty is that police standards vary, as does the calibre of personnel. Some seem to experience considerable difficulty in distinguishing underprivileged from underworld characters, and the abuses associated with unlawful detention are not confined to the psychic coercion inherent in protracted questioning by relays of officers.

These things happen because the safeguards upon which the ambivalent traditional confessions rule depends are illusory. A suspect being questioned before arraignment is usually alone with the officers, and what happened becomes an issue of his word against theirs. Such an issue is difficult enough for a trial court, and the appellate courts are even further from the facts.

50. Smith, Municipal Police Adminisiration (1929) 146 ANNaLs 1.

51. See Comment (1944) 53 YALE L. J. 758, 760-1; Note (1935) 94 A. L. R. 1036. 
By 1943 there were hints that the Supreme Court had grown dissatisfied with prevailing arrangements for protecting the rights of accused persons in criminal proceedings. In recent cases involving confessions by suspects who were mentally inferior to their interrogators the Court had displayed a new sensitivity to the potentialities of psychic coercion. ${ }^{52}$ In others coming up by way of habeas corpus from the penitentiaries in formo pauperis and on painfully handwritten, home-made briefs, the Court had begun to scrutinize with a sceptical eye alleged waivers by the accused of his right to representation by counsel. ${ }^{53}$

The cases in which the Supreme Court rejected the traditional compromise on police detention and questioning and advanced its new formula need not now be dwelt on. One-Anderson v. Unitcd States s8 -was a prosecution of twenty-one members of the International Union of Mine, Mill, and Smelter Workers for conspiracy to damage property of the TVA (during an obdurate labor dispute at one of the Tennessee Copper Company's mines in an atmosphere of charges and counter charges of violence some power lines had been dynamited), and the other-the $M C C N a b b^{55}$ - was a prosecution of five Tennessee mountaineers for the killing of a federal officer during an encounter between moonshiners and revenue agents.

In both the government relied on confessions. Those in the Anderson case were obtained from six of the suspects while they were being held with fourteen others in a company building which was also used to house the local sheriff's special deputies, and were the product of intermittent questioning by F.B.I. agents over a period of about six days during which time the prisoners were not arraigned before any judicial officer. In the $M C N a b b$ case four of the accused were arrested in the early hours of the morning after the shooting, and the fifth was voluntarily taken into custody on the following morning. They were questioned intermittently by agents of the Alcohol Tax Unit up to about 2 a.m. of the third morning after the shooting, being in custody all this time. (Each had actually been arraigned promptly before a Commissioner on a bootlegging charge, but this independent proceeding did not appear in the record transmitted to the Supreme Court).

The Supreme Court reversed the convictions in these cases on March 1, 1943. In each Justice Frankfurter spoke for the majority. What made the reversals news to the police and the legal profession was the fact that the Court did not treat these as "third degree cases" and dispose of them on the basis of the seeming voluntariness or in-

52. See Lisenba v. California, 314 U. S. 219 (1941).

53. See Walker v. Johnston, 312 U. S. 275 (1941); Johnson v. Zerbst, 304 U. S. 453 (1938).

54. 318 U. S. 350 (1943).

53. 318 U. S. 332 (1913). 
voluntariness of the confessions. The Court neither assumed nor found that any of the defendants had been physically mistreated, beyond the fact that they had apparently been detained incommunicado for questioning in "plain disregard" of the legislative policy of prompt arraignment. The objective of that policy, as the Court saw it, was not merely to protect the innocent, but to secure "conviction of the guilty by methods that commend themselves to a progressive and self-confident society," and to outlaw "easy but self-defeating ways in which brutality is substituted for brains as an instrument of crime detection." The Court had apparently come to the conclusion that the only way to eliminate third degree abuses which-when they do occur-are invariably associated with incommunicado detention, was to insist that there be no incommunicado detention even for a day or two, and even though those detained may be well treated, in any case. To discourage non-compliance the Court proposed to exclude all evidence procured in violation of the prompt arraignment policy. The new strategy was to eliminate both the opportunity and the temptation to abuse.

Justice Reed, dissenting, considered the defendants in both cases guilty, and their confessions entirely voluntary. Nor did he approve the new strategy, being "opposed to broadening the possibilities of defendants escaping punishment by these more rigorous requirements in the administration of justice." Many of the lower federal courts agreed with him, and with unconcealed hostility to the new approach began excluding statements and reversing convictions in pending cases on the slightest of pretexts. Some were so transparent, indeed, that Attorney General Biddle expressed himself as "unable to understand why the trial courts should exhibit the passion for excluding statements which some of these decisions reveal." 56

Opposition to the $M c N a b b$ rule came to a head in a bill ${ }^{67}$ introduced by Representative Hobbs of Alabama. It was short and to the point:

"Be it enacted ... That no failure to observe the requirement of law as to the time within" which a person under arrest must be brought before a magistrate, commissioner, or court shall render inadmissible any evidence that is otherwise admissible."

Hearings were held before the House Judiciary Committee during the fall and winter of 1943. "Let us now," urged the Congressman, "wipe out the $\mathrm{McNabb}$ rule that is playing havoc with law enforcement,

56. Heariugs before Subcommittee No 2 of the Committee on the Judiciary on $H . R .3690$. 78th Cong. 1st Sess. (1943) 33. See the discussion of some of these cases in Comment (1944) 53 YALE L. J. 785, 763-4.

57. H. R. 3690, 78th Cong., 1st Sess. (1943) introduced on November 18, 1943, and re. introduced at the 2 nd Session. The House Committee on the Judiciary reported the bill favorably, with certain amendments, and in the next Congress it passed the House. 
punishing the innocent public while guilty criminals go free." The effect, he said, would be "like putting on an old shoe." :3 Police spokesmen supported the bill. Superintendent Kelly of the District of Columbia police told the Committee that a prisoner "when he arrives at the jail or place that he is committed [after arraignment], receives all linds of advice and information from other persons held in jail-namely, those that are referred to as tier lawyers-and then it is absolutely impossible to proceed further in a proper manner with the investigation." 59

"I get the impression," said Congressman Cravens of Arkansas, "that the purpose of not taking him before the magistrate is to keep him from getting advice." "No, sir," replied Kelly, "I believe that every person should be guaranteed the right provided under the Constitution of the United States, but at the same time I believe . . . that when a person is charged with the commission of a serious crime, there should not be any interference with the police or detectives until such case is brought to a definite conclusion. I do not mean that a person should be held forever, but should be allowed to stay in the custody of the police for a reasonable time until the investigation is concluded." 0

The bill was opposed by labor spokesmen, and Lee Pressman of the C.I.O. reminded the Committee that in England the judges of the King's Bench had prescribed rules for the interrogation of prisoners while in the custody of the police. Why, he asked, did the Judiciary Committee not likewise face the problem and request the Department of Justice to submit proposed rules, with a view to a solution protecting individual rights while taking care of the exceptional cases of which the police spoke? ${ }^{61}$

Attorney General Biddle pointed out to the Committee that the Hobbs bill would leave the statutory right to immediate arraignment (along with an opportunity to the defendant to obtain counsel and release on bail) where it was, "and the Congress would presumably intend the rules to be respected even though the evidential sanction were removed." The arraignment statutes, he felt, should be modified to allow for exceptional cases, and he recalled the Nazi saboteurs who landed on Long Island:

". . . Mr. Hoover called me, I think it was Thursday night when the first saboteur was arrested. The last one was not arrested until 8 or 9 days later. If we had arraigned the first one immediately, that would have forewarned the other seven who were in

58. Hearings, note 56 supra at 128.

59. Id. at 6 .

60. Id. at 6 .

61. Id. at 97. The English rules and experience are discussed in Comment (1944) 53 YALE L. J. 758, 767-769. 
possession of these dangerous implements. Therefore, I specifically had to disregard the law requiring me to arraign all of them immediately, for the preservation of the country. I thought it my duty to do that. In the kidnapping cases, if the first one of a gang caught is immediately arraigned, the others are immediately put on notice as to what has happened. It is a serious proposition. A reasonable time standard would seem to me to justify delay for such purposes and to achieve such ends." 62

As passed by the House the bill ${ }^{63}$ was modified to require arraignment "within a reasonable time," and provided that while failure so to do should "not render inadmissible any evidence that is otherwise admissible" such failure should be "prima facie evidence that any admission or confession made . . . during the time of such unreasonable detention was made under duress."

What would be the criteria of reasonableness, and of duress? ${ }^{4}$ From the bill alone one might gather that the House wanted to refer the whole problem back to the Court, unhampered by the rigid provisions of the arraignment statutes. The Committee Report (Judiciary No. 245 ), however, explained the bill as a temporary measure which would "merely nullify the new rule of the McNabb decision," and "declare that no such policy . . . underlies the laws Congress passed requiring prompt arraignment." It would give the Committee "time, without the pressure and penalty of suspended law enforcement, within which to study these delicate and difficult problems . ..."

The suggestion that federal law enforcement was suspended by the $M c N a b b$ decision is interesting, in view of the unconvincing factual evidence produced before the Judiciary Committee. ${ }^{65}$ The pity is that more would be known about this had it not been for the stony resistance of enforcement officials to the sheer raising of this issue which for cen-

62. Hearings, note 56 , at 35-6.

63. H. R. 43, 79th Cong., 1st Sess. (1944).

64. In the course of the hearings the National Sheriffs' Association endorsed the principles of the proposed Uniform Arrest Act-which would countenance detention for investigation (not to be considered an arrest) by the police for not more than two hours when reasonable ground for suspicion exists, and which would require arraignment after arrest without unreasonable delay and in any event within 24 hours (Sundays and holidays excluded) unless a judge for good cause shown orders a further postponement for an additional period of not more than 48 hours. See Warner, The Uniform Arresl Act (1942) 28 VA. L. REv. 315, 343-347. Such a procedure would facilitate the production of prisoners at the police line-up. It would give the police all the time they need for questioning in the ordinary run of not too difficult cases. It would not, however, have solved the Attorney General's problem in the Saboteurs' case, nor would it have sufficed for the kidnapping cases cited by Mr. Hoover, or, for that matter, in the Anderson case.

65. Hearings, note 56, at 31 et seq. The Attorney General cited about a dozen reversaly, including the Gros espionage case, the Haupt treason case, the Rutnels murder case (in which there was incommunicado detention for 17 days by State deputy sheriffs), the Wilborn case of attempted rape and the Johnston case of stabbing assault. In addition to these the 
turies has pressed for solution. The $M c N a b b$ rule has now been in force for over three years-long enough, had the Department of Justice and the federal police agencies accepted the venture and bent their energies to giving the new approach a fair trial, to have developed a significant record of experience. Objections at the outset that the new rule would not work were useful only as hypotheses to be tested; for once the decision had been handed down it was obvious that the new rule would prevail for some period of time.

Read against this background, a suggestion in the Committee Note to Rule 5(a) may be misleading. The Note states:

". . . What constitutes 'unnecessary delay,' i.e., reasonable time within which the prisoner should be brought before a committing magistrate, must be determined in the light of all the facts and circumstances of the case. . . ."

But, obviously, the question is whether the duty of arraignment "without unnecessary delay" permits an arresting officer only such time as may be needed to bring the offender before the nearest available magistrate, or whether, in addition, it permits a certain amount of time for interrogation and investigation. The decisions of the Court, beginning with the $M c N N a b b$ case, clearly suggest the former interpretation. The language of Rule 5(a) works in no different direction. The $M C N a b b$ rule, as is generally recognized, departs from the prevailing state practice in this regard, and yet the Committee Note,-which is, of course, unofficial-goes on to state that Rule 5(a) "also states the prevailing state practice," citing the Commentaries to Sections 35 and 36 of the A.L.I. Code of Criminal Procedure.

District of Columbia police, more than 8 months after the AfcNabb decision, reported some 24 cases in the District as having been affected by the new rule. Several rivere cares of petit larceny (one involved the theft of some old rags, another of a saxophone). In 4 more ( 2 of murder and 2 of theft) the only complaint was that statements obtained from the accused could not be used in evidence, there being no suggestion that other evidence was not available. In 12 more, including 7 burglaries and 2 robberies, the only complaint was that the II $\mathrm{Nabb}$ rule had precluded presentation of the accused at the nightly "police line-up" which might have developed evidence of other offenses, but all were convicted of their linown crimes. Eight cases of individuals believed by the police to be guilty but whose convictions were reversed by reason of the $A F C N a b b$ rule made up the balance, 4 for murder, and 2 for robbery being the most serious.

Presumably the list could be supplemented by similar cases occurring after November, 1913 , in the District of Columbia and elsewhere in the United States. As it is, this handful of cases constitutes the record to support the opinion that the $M$ C Nabb rule is playing havos with federal law enforcement. There is no way of judging from the outside whether the police work in any of them was up to standard; and during the eight months period which they represent, a total of some 36,000 federal criminal cases vere disposed of, according to Representative Hobbs' estimate at the hearings.

66. Notes to the Rules of Crminal Procedure for the Distruct Courts of tae United States (1945) 4. 
Subdivisions (b) and (c) of Rule 5 govern the proceedings before the commissioner. As under the previous practice, ${ }^{67}$ the defendant is to be informed of the complaint against him, of his right to retain counsel and of his right to have a preliminary examination. $\mathrm{He}$ is also to be advised that he is not required to make a statement, and that any statement made by him may be used in evidence. Examination may be waived by the accused, and in any event subdivision (c) provides that he "shall not be called upon to plead." This latter provision is based on considerations of fairness, having in mind that most defendants are not represented by counsel at this stage. ${ }^{68}$

The rule does not provide for interrogation of an accused by the commissioner. Such provision has been proposed by Professor John B. Waite and others, who argue that "prompt interrogation, even after explicit warning that answer is unnecessary and may be dangerous, does seem in actuality to produce information which is more difficult to obtain later and which, when so obtained by a commissioner, is less subject to suspicion than when obtained by the police." ${ }^{60}$ In rejecting the proposal the Committee was influenced in part by the prevalent feeling that such a procedure would probably be in violation of the privilege against self-incrimination, and in part by the consideration that most commissioners are part time officers, frequently not lawyers and unskilled in the art of examination. Unlike the European juge d'instruction, our commissioners have neither the facilities nor the time to examine investigative reports.and interview witnesses as a basis for effective interrogation of an accused. ${ }^{70}$

67. See Manual For United States Commissioners, published by the Administrative Office of the United States Courts.

68. A plea of guilty before the commissioner entered by a defendant unrepresented by counsel has been held inadmissible in evidence. Wood v. United States, $128 \mathrm{~F}$. (2d) 265 (App. D. C. 1942). The technical nature and status of the proceedings before the commissioner are discussed in Todd v. United States, 158 U. S. 278 (1895).

69. See the Supplement to Federal Rules of Criminal Procedure, Preliminary DRafT (1943) 249-50.

70. Id., at 253-4. 